\title{
USER ACCEPTANCE OF ONLINE WAQF APPLICATIONS : EVIDENCE FROM INDONESIA
}

\author{
Taufik Faturohman ${ }^{1}$, Irfan Hassandi ${ }^{2}$ and Yulianti ${ }^{3}$ \\ ${ }^{1}$ SBM Institut Teknologi Bandung, Indonesia, taufik.f@sbm-itb.ac.id. \\ ${ }^{2}$ SBM Institut Teknologi Bandung, Indonesia, irfan_hassandi@sbm-itb.ac.id. \\ ${ }^{3}$ SBM Institut Teknologi Bandung, Indonesia, yulianti@sbm-itb.ac.id
}

\begin{abstract}
Waqf is an Islamic asset endowment to be kept in faith and used for charitable or religious purposes. Its function is to demonstrate the potential and economic benefits of waqf assets for worship and other people's prosperity. Indonesia has great opportunities to raise more significant amounts of waqf funds. One strategy that appears effective with regard to waqf, especially cash waqf, is to provide an online service. Hence, this research attempts to analyse whether the perceived usefulness, perceived ease of use, perceived religiosity, and amount of information influences user acceptance of using an online waqf application process by implementing the technology acceptance model (TAM). Moreover, the study incorporates structural equation modelling (SEM) to interpret the path analysis of the model. The study fills the gap in the literature concerning the context of use of the technology acceptance model for online waqf applications in Indonesia. We find that the variables that directly influence user acceptance of online waqf application are perceived usefulness and perceived ease of use, with perceived ease of use influencing perceived usefulness. In addition, perceived ease of use is influenced by the amount of information. Furthermore, the majority of respondents prefer to have projects such as mosques, Islamic boarding schools, schools, and hospital construction projects. To increase user acceptance, online waqf developers should provide more information about the application process and develop more user-friendly software with many features. Moreover, regulators should provide incentives for online waqf developers to maximise cash waqf collection.
\end{abstract}

Keywords : User intention, Online waqf application, Technology acceptance model (TAM), Structural equation model (SEM).

JEL Classification: G2; G20; G21.

Article history:

Received : October 22, 2019

Revised : November 21, 2019

Accepted : February 9, 2020

Available online : August 25, 2020

https://doi.org/10.21098/jimf.v6i3.1117 


\section{INTRODUCTION}

\subsection{Background}

Waqf is an Islamic asset endowment to be kept in faith and used for a charitable or religious purposes. Its function is to manifest the potential and economic benefits of waqf assets for worship and other people's prosperity .

Indonesia manages 49,230.38 hectares of property waqfs at 361,337 sites. Approximately $44.87 \%$ of land assets have been developed into mosques, $28.12 \%$ into prayer rooms, $10.61 \%$ into schools, $4.56 \%$ into cemeteries, $3.34 \%$ into Islamic boarding schools, and $8.50 \%$ into other social assets that are useful for the community (Badan Wakaf Indonesia, 2019). Moreover, IDR 400 billion of cash waqfs is managed (Fadhilah \& Nur, 2018).

The Indonesia Waqf Board (Badan Wakaf Indonesia, or BWI) manages waqf operations. It was established following the publication of Law No.41 Year 2004 by the government. In practice, BWI was established as an organization to manage waqf assets (nazhir) with the aim of having a beneficial effect on social activity, economics, and infrastructure (Badan Wakaf Indonesia, 2019). BWI also appointed 18 sharia financial institutions to collect cash waqf funds from waqif. This institution is called LKS-PWU (Lembaga Keuangan Syariah-Penerima Wakaf Uang).

Today, in line with the growth of technology, many instruments can make people's lives simpler. As stated by Cahyono (2016), the internet is one such tool, which makes it easier for people to access many borderless items in all countries and regions. There are 171.17 million internet users, or $64.8 \%$ of the total population, in Indonesia, a number which is rising by around 10.12\% per year (APJII, 2018).

Many services can be accessed by internet users, with interaction via email and social media, and the possibility to watch videos and do other activities. Online banking systems have been created to ensure that customers can easily make transactions without going to the bank.

Online waqf in Indonesia provides several financial services appointed by BWI to handle cash waqf funds; for example, Bank of Syariah Mandiri provides jadiberkah.id as its internet waqf platform, and BNI Syariah its Wakaf Hashanah. Furthermore, other financial technology companies such as Ammana Fintech and kitabisa.com also provide online waqf services. Based on Google Play data from 18th June 2019, almost 10,000 people had installed Ammana Fintech, and 100,000 people kitabisa.com, while 1,000 had installed Wakaf Hashanah of BNI Syariah, and 100 Mobile Wakaf of BTN Syariah.

BWI states that the waqf asset potential in Indonesia is around IDR 2,000 trillion, with a land area of 420 hectares per year. Furthermore, cash waqf potential is IDR 188 trillion per year, although the current amount is only IDR 400 billion (Republika, 2019). The potential of waqf is tremendous; however, in practice, the receipt of cash waqf funds is still below its potential. Technology has been used and implemented in internet waqf applications so that cash waqf from waqif can be simply attained. If we realise the cash waqf potential of internet banking users, at least IDR 9 trillion could be collected per year, as calculated by the multiplication of the IDR 188 trillion cash waqf potential, and the number of internet users at $64.8 \%$ of the total population, $7.39 \%$ of whom access banking services. 


\subsection{Objective}

As previously mentioned, Indonesia has tremendous waqf potential, including cash waqf, due to its status as one of the most populous Muslim nations in the world. The number of Muslims in 2015 was 219 million, nearly $87 \%$ of the country's total population. The internet waqf application is expected to realise the potential of cash waqf. Therefore, this study evaluates the factors which affect user acceptance of internet waqf applications. The results of the study are expected to maximise the performance of the platform to capture cash waqf in Indonesia. The study fills the gap in the literature regarding the context of the technology acceptance model with regard to online waqf application in Indonesia.

\section{LITERATURE REVIEW}

\subsection{Background Theory}

\subsubsection{Waqf Concept and Application}

Etymologically, waqf means hold, confinement or prohibition. In the terminology of Islamic laws, it means holding certain assets and preserving them for the confined benefit of a certain philanthropy, and prohibiting any use or disposition of them outside their specific objective benefits (Kahf, 2003). Waqf is also called al-Habs, which means holding, stopping, or silence. If the word is associated with assets such as land or animals, it means attaching ownership of these to certain benefits (Masrikhan, 2019). From this definition, waqf is an Islamic asset endowment to be kept in faith and used for a charitable or religious purpose. Its function is to manifest the potential and economic benefits of waqf assets for worship and other people's prosperity. Waqf practices began in the period of the Prophet Mohammad, and was later institutionalised in the eighth century A.D. (Darus et al., 2017)

In Islamic knowledge, especially in the holy Quran and hadith, there is no specific information about waqf, so in explaining it the Quran uses the term "infaq fi sabilillah" to explain how vital waqf and infaq are in Islam. "You do not come to goodness before you spend what you loved" (Q.S. Ali Imran (3):92) and "You who have believed, spend (in the way of Allah) what you have earned from your good work and some from the things that we give to you from the result of the earth" (Q.S. Al-Baqarah (2):267). Besides the Quran, there is a hadith explaining the importance of waqf: "If a human die, then his charity is interrupted except from three resources, jariyah alms, knowledge that has been utilized, and good children who pray for them" (H.R. Muslim No.1631).

In implementing waqf, it is necessary to fulfil certain requirements according to sharia knowledge, which is called rukun waqf and which refers to the people who want to undertake waqf (al-waqif), the asset that will be endowed (almaufuq), the people who will receive the waqf (al-mauquf'alaihi), and the waqf vow (Badan Wakaf Indonesia, 2019). If the rukun waqf is not fulfilled, the waqf is not acceptable. Nazhir is the party that is assigned to accept the waqf treasury from the wakif (the person who does the waqf), who is obliged to manage the waqf fund/treasury according to its designation and to distribute its benefits to the legal community (mauquf alaihi). Based on 11th D and 14th verse UU No.41-year 2004 about waqf, Nazhir registers its organisation with BWI, to whom it also reports the implementation of its retribution (Badan Wakaf Indonesia, 2019). 
Regarding the rules of rukun waqf, certain requirements need to be fulfilled. The al-waqif needs to be an independent, clear-minded adult, and not forgiven . The al-maufuq (the donated asset) must have benefit, and be a transferred asset or static asset that is donated as waqf, and an asset which is owned by the alwaqif and known by all parties when a waqf takes place. Concerning al-Mauquf' Alaiha, when making an endowment, it has to be stated to whom the waqf will be distributed and its purpose (for example, for worship). (Badan Wakaf Indonesia, 2019).

In addition to the waqf requirements, there is also the necessity for an asset to be endowed. Indonesian law sets out what kind of assets can be endowed. Law No.41, year 2004, 16th clause, 1st verse explains that two primary assets can be endowed: movable and immovable ones. Immovable assets are classified as land rights following the provisions of the legislation to those who have registered and not yet registered. Examples of static assets are buildings or parts of buildings on the ground, plants and other land-related subjects, and other immovable objects under the provisions of the Sharia law and applicable laws and regulations (Law No.41, year 2004, 16th clause, 2nd verse).

Movable assets are classified as those that cannot be exhausted due to consumption. According to Sadeq (2002), besides land assets, cash waqf is also used for certain purposes. In early practice, it was established by the wealthy for specific purposes. The endowed cash used to be invested or loaned out to earn income, and this earned income financed the target projects. In response to the necessity of cash waqf, Majelis Ulama Indonesia (MUI, Indonesian Ulama Council) issued a fatwa (decision) on 11th May 2002, as follows:

1. Cash waqf (Waqf al-Nuqud) is a waqf that individuals, groups, or institutions are donated in the form of cash;

2. Cash waqf includes securities;

3. Cash waqf is allowed;

4. Cash waqf can only be distributed and used based on sharia law; and

5. The principal value of waqf must be guaranteed for sustainability. Waqf funds cannot be sold, granted, and/or inherited.

The cash waqf scheme implemented in Indonesia is the Waqf Share Scheme, as shown in Figure 1, which is also adopted for online cash waqf activity. The purpose of the scheme is to generate public money to support the welfare of society. This cash generation activity aims to finance legitimate products and services in society. The value that must be achieved by the cash waqf is to ensure that it is collected from the various parties and should first be invested, with the profit gained distributed to the beneficiaries (Mohsin, 2013). 


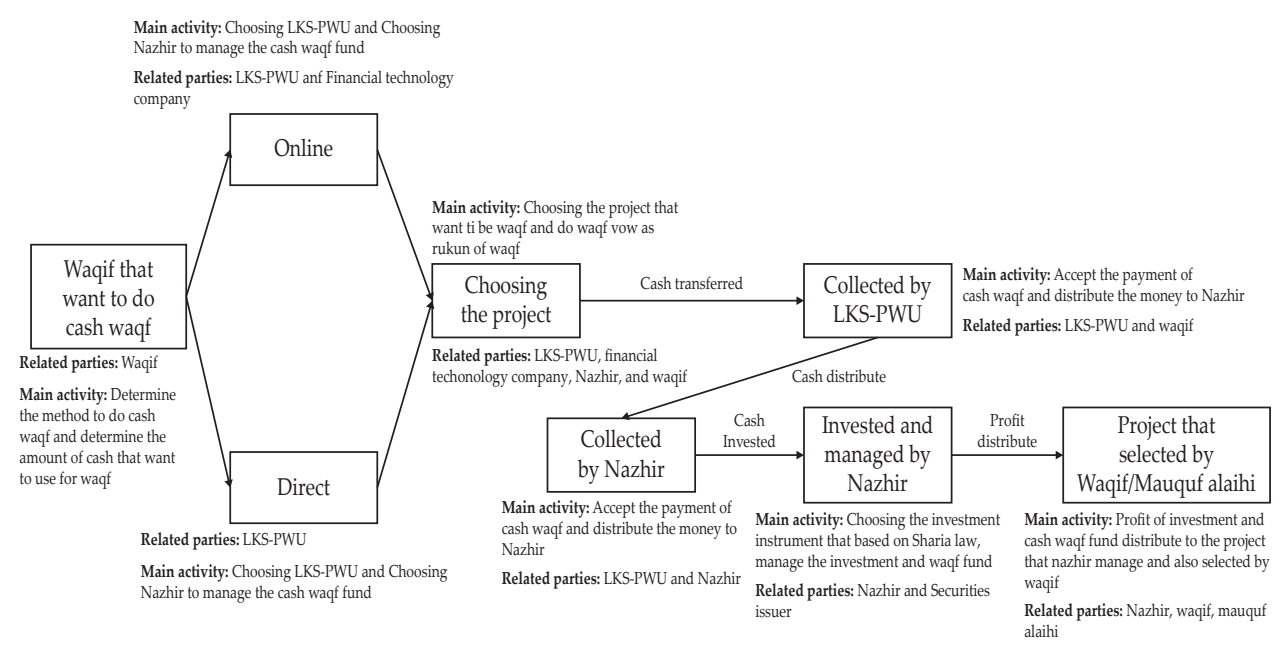

Source: BWI (2019)

Figure 1.

Cash Waqf Scheme Adopted to Online Waqf Scheme

Waqf is not only implemented in Indonesia, but also in several other countries such as Malaysia, Singapore and India. Its main goals in all countries are the same: to have a positive impact on many people.

\subsubsection{Technology Acceptance Model (TAM)}

The research mainly uses the Technology Acceptance Model (TAM) proposed by Davis, Bagozzi, \& Warshaw (1989), which is used to analyse factors that influence people when adopting technology. The basic TAM examines two variables, perceived usefulness (PU) and perceived ease of use (PEOU), and relates them to the use of new technology. The model is widely used for measuring people's acceptance because it is easy to use, less expensive to apply, and can predict acceptance of use relatively well (Davis et al., 1989). Figure 2 shows the basic TAM.

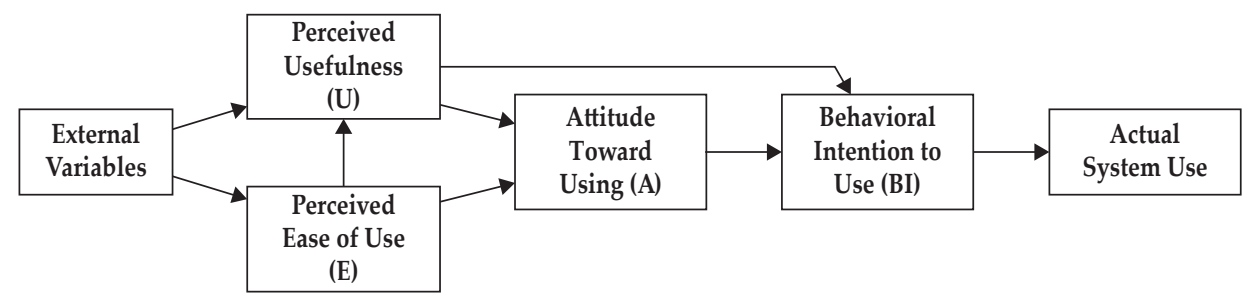

Source: Davis (1989)

Figure 2.

Basic Technology Adoption Model 
PEOU is defined as the point at which individuals think that if they use the scheme, they will be unimpeded in their attempts, whereas PU is the point at which individuals think that their output will be boosted through the use of a specific scheme. Furthermore, there are multiple external variables that can affect consumers' perception of a system's ease and utility. While the intention to use refers to the willingness of the user to execute a certain behaviour, real use is determined by how many times customers interact with the scheme (Chuttur, 2009).

\subsection{Previous Studies}

In generating the model and the variables used in this research, a literature review of previous research that has also used the TAM was conducted. Related studies have observed the relationships between variables and user acceptance.

Kumar, Alan, \& Bannerjee (2004) examined user perceptions of gathering information on locating and buying compact discs through web-based interfaces. Their study was conducted in Hong Kong during the summer of 2001. ANOVA was employed to measure the user interface features associated with the perception of overall ease of use. They found there were differences based on the personal characteristics of respondents, and furthermore that differences in the perceptions of interface features that might be due to personal characteristics, such as age and sex.

Pikkarainen, Pikkarainen, Karjaluoto, \& Pahnila (2004) studied online banking acceptance using a traditional TAM that was adjusted to the online environment. Based on a focus group interview with banking professionals, TAM literature and e-banking studies, they developed a model indicating online banking acceptance among private banking customers in Finland. The model was tested with a survey of 268 respondents. They found that perceived usefulness and information on online banking on websites were the main factors influencing online banking acceptance.

Amin (2007) used the TAM to measure acceptance of internet banking among undergraduate students in Malaysia. The model employed perceived usefulness (PU), perceived ease of use (PEOU), perceived credibility (PC) and computer selfefficacy (CSE). PU and PEOU were the initial constructs for the model, while PC and CSE were new constructs included in the model to better reflect students' views. The results suggested that PU, PEOU and PC had a significant relationship with behavioural intention. Furthermore, these measures were functional determinants for undergraduate students' acceptance of internet banking. Their results also suggested that PU and PEOU had a significant relationship with CSE. In contrast, CSE was not associated with PC, and PEOU also had a significant relationship with PU and PC, indicating that these scales were related to PEOU in explaining undergraduate preference.

Racherla and Friske (2012) used linear regression to measure 3000 reviews obtained from Yelp.com, a popular online advisory site dedicated predominantly to various types of services across major cities in the United States. The results showed that the combination of both reviewer and review characteristics significantly correlated with the perceived usefulness of the reviews. They also 
obtained several results that were anomalous to the established knowledge related to consumers' information consumption, both offline and online.

Amin, Rahman, Ramayah, and Supinah (2014) analysed the technology acceptance of online waqf in Kota Kinabalu, East Malaysia. They studied 158 customers of Malaysian Islamic banks from November to December 2012. The variables used in their research were perceived ease of use, perceived usefulness, perceived religiosity, amount of information, and user acceptance. The study found that perceived usefulness and perceived ease of use explained the reasons for people's intention to use online waqf, together with the importance of religiosity and its impact on acceptance. Moreover, the amount of information was also crucial to online waqf acceptance.

Suhud, Wibowo, Khairi, \& Willson (2019) implemented the TAM to measure response acceptance to taxi-hailing in Jakarta, Indonesia. The study focused on 200 participants, and the TAM predictor variables included perceived ease of use (PEOU), perceived usefulness (PU), and attitude toward behaviour. Data were analysed using exploratory and confirmatory factor analysis. The study found that PEOU significantly affected attitudes towards usage and PU, while PU significantly affected attitude and intention to use, and attitude significantly affected intention to use.

Previous studies show that no research examining user acceptance of online waqf application in Indonesia has been conducted. Therefore, this study adopts the TAM method to maximise the potential of untapped cash waqf in Indonesia, and fills the gap in the literature concerning the context of the technology acceptance model in relation to online waqf application in Indonesia.

\section{METHODOLOGY}

\subsection{Data}

The study used confirmatory factor analysis (CFA), and structural equation modeling (SEM) methods. The minimum sample to acquire parameter estimates with low standard error is 150 (Anderson \& Gerbing, 1988). The population for the research had to fulfil the following criteria: first, that they were Muslim living in Indonesia; and second, that they had experience of online transactions, but had never been involved with waqf using online waqf applications. People who have experience of making online transactions know what to do in the related process. 253 data items were collected as the sample of the study.

Primary data were gathered using an online questionnaire based on the convenience sampling method. The outcome of the questionnaire was processed using a quantitative approach. The questionnaire employed a Likert scale from 1 to 5 (1: strong disagreement, 2: disagreement, 3: undecided, 4: agreement, 5: strong agreement) and comprised three filtering issues about religion, internet transaction experience, and online waqf application experience. It also included six descriptive questions about gender, age, last education, job, earnings, and the proportion for charity. In order to measure the variable in the suggested model, the questionnaire comprised 12 questions, covering perceived usefulness, perceived ease of use, amount of information, and acceptance by the customer. 
The questionnaire used was adapted from that of Amin et al. (2014), which measured user acceptance of online waqf application in Malaysia. Assumptions were made in determining the respondents' understanding of the differences between infaq, waqf, alms and zakat. Due to the sampling method and the convenience sampling used, the research faced time limitations for its completion. Table 1 shows the questionnaire design employed. The variables used werre latent, as they were indirectly measured by the questionnaire. According to Hair, Black, Babin, \& Anderson (2014), a latent variable is a hypothesised and unobserved concept that can be represented by observable or measurable variables. It is measured indirectly by examining consistency among multiple measured variables, which are gathered through various data collection methods (e.g., surveys, tests and observational methods).

Table 1.

Questionnaire Design

\begin{tabular}{|c|c|c|}
\hline $\begin{array}{l}\text { Latent Variable } \\
\text { and Sources }\end{array}$ & Code & Research Item \\
\hline \multirow{5}{*}{$\begin{array}{l}\text { Perceived Usefulness } \\
\text { Sources: Davis (1989), } \\
\text { Amin et al. (2014), } \\
\text { Tang and Chiang (2009) }\end{array}$} & PU1 & $\begin{array}{l}\text { Using the online waqf application will improve my performance } \\
\text { when doing charity activities. }\end{array}$ \\
\hline & PU2 & $\begin{array}{l}\text { Using the online waqf application will make it easier for me to } \\
\text { do charity activities. }\end{array}$ \\
\hline & PU3 & $\begin{array}{l}\text { I think using the online waqf application will be useful in } \\
\text { carrying out charitable activities. }\end{array}$ \\
\hline & PU4 & $\begin{array}{l}\text { Using the online waqf application allows me to do charity } \\
\text { activities faster. }\end{array}$ \\
\hline & PU5 & Using the online waqf application can increase my productivity. \\
\hline \multirow{5}{*}{$\begin{array}{l}\text { Perceived Ease of Use } \\
\text { Sources: Amin et al. } \\
\text { (2014), } \\
\text { Pikkarainen et al. (2004) }\end{array}$} & PEOU1 & $\begin{array}{l}\text { I think it is easy for me to learn how to use the online waqf } \\
\text { application. }\end{array}$ \\
\hline & PEOU2 & $\begin{array}{l}\text { I found it easy to do what I wanted to do when doing waqf with } \\
\text { an online system. }\end{array}$ \\
\hline & PEOU3 & $\begin{array}{l}\text { Using the online waqf application makes interaction more } \\
\text { flexible. }\end{array}$ \\
\hline & PEOU4 & I think using waqf online is more comfortable and fun \\
\hline & PEOU5 & Learning about waqf online is easy to understand. \\
\hline \multirow{5}{*}{$\begin{array}{l}\text { Perceived Religiosity } \\
\text { Source: Amin et al. } \\
\text { (2014) } \\
\text { Mokhlis (2009); } \\
\text { Ahmad, Rahman, Ali, } \\
\text { and Seman (2008) }\end{array}$} & PREL1 & I make financial contributions to my religion. organization \\
\hline & PREL2 & Religion affects all decisions in my life. \\
\hline & PREL3 & I often read books or magazines about my religion \\
\hline & PREL4 & I enjoy spending time studying my religion. \\
\hline & PREL5 & My religion is my life guide. \\
\hline \multirow{3}{*}{$\begin{array}{l}\text { Amount of Information } \\
\text { Source : Amin, Rahman, } \\
\text { Ramayah , Supinah. \& } \\
\text { Aris (2014) }\end{array}$} & AOI1 & I often get information about waqf online. \\
\hline & $\mathrm{AOI} 2$ & $\begin{array}{l}\text { I get enough information about the benefits of using the online } \\
\text { waqf application }\end{array}$ \\
\hline & AOI3 & $\begin{array}{l}\text { I have received information about using online waqf applications } \\
\text { from several media. }\end{array}$ \\
\hline
\end{tabular}


Table 1.

Questionnaire Design (Continued)

\begin{tabular}{|c|c|c|}
\hline $\begin{array}{l}\text { Latent Variable } \\
\text { and Sources }\end{array}$ & Code & Research Item \\
\hline \multirow{5}{*}{$\begin{array}{l}\text { User Acceptance toward } \\
\text { Waaf Application } \\
\text { Amin (2007), } \\
\text { Suhud et al. (2019) } \\
\text { (Amin. H, Rahman. } \\
\text { A.R.A, Ramayah. T., } \\
\text { Supinah. R., Aris. M.M, } \\
\text { 2014) }\end{array}$} & UAWA1 & I intend to use the online waqf application. \\
\hline & UAWA 2 & I tend to use the online waqf application as much as possible \\
\hline & UAWA 3 & $\begin{array}{l}\text { I will use the online waqf application as part of my charity } \\
\text { activities in the future }\end{array}$ \\
\hline & UAWA 4 & $\begin{array}{l}\text { I will use the waqf application online more often. during } \\
\text { Ramadhan. }\end{array}$ \\
\hline & UAWA 5 & $\begin{array}{l}\text { Overall, I will use the online waqf application for my Charity } \\
\text { Activities. }\end{array}$ \\
\hline
\end{tabular}

Note: $\mathrm{PU}=$ Perceived Usefulness, $\mathrm{PEOU}=$ Perceived Ease of Used, AOI = Amount of Information, UAWA $=$ User Acceptance toward Waqf Application

\subsection{Model Development}

Amin et al. (2014) modified the basic TAM model to analyse online waqf acceptance in Malaysia. Two variables were added to the model, perceived religiosity and amount of information. Figure 3 shows the modification of the model proposed by Amin et al. (2014).

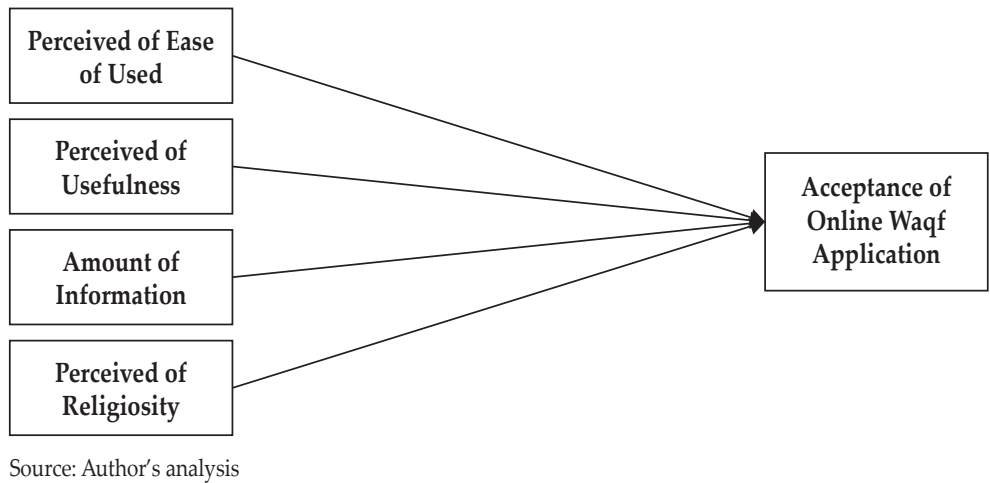

Figure 3 .

Modification of the TAM Model (Amin et al., 2014)

This study adopts the model implemented by Amin et al. (2014). In our proposed model, the hypothesis testing focused on the relationship between the variables and online waqf acceptance. Pikkarainen et al. (2004) found that that there was a positive relationship between perceived ease of use and user acceptance. In this research, we analyse whether the perceived ease of use influences user acceptance in online waqf application .

\section{H1: Perceived ease of use influences user acceptance.}

Amin et al. (2014) and Tang and Chiang (2009) found that there was a positive relationship between perceived usefulness and user acceptance. Based on these 
studies, we investigate whether perceived usefulness influences user acceptance in online waqf application.(Tang \& Chiang, 2009)

H2: Perceived usefulness influences user acceptance.

Mokhlis (2009) found that religiosity is a relevant variable that can be used in marketing research, especially research that relates to behaviour. Ahmad, Rahman, Ali, and Seman (2008) also found that religion is a factor that influences people when choosing a bank. In addition, religiosity is a factor that influences peoples' choice of products provided by banks to their customers. Therefore, this research was conducted to ascertain whether perceived religiosity influences user acceptance of online waqf application.(Wan Ahmad, W.M., Ab Rahman, A., Ali, N.A., \& Seman, 2008)

H3: Perceived religiosity influences user acceptance.

Amin et al. (2014) found that the amount of information has a positive relationship with the behavioural intentions of users. Their paper also explains that the amount of information has a better ability to predict and demonstrate the intention of consumers to adopt certain products. Therefore, it is interesting to establish whether the amount of information influences user acceptance in online waqf application.

H4: The amount of information influences user acceptance.

Amin (2007) and Suhud et al. (2019) explain that perceived ease of use influences perceived usefulness. With these findings, we also aim to identify whether or not perceived ease of use influences perceived usefulness in online waqf application.

H5: Perceived ease of use influences perceived usefulness.

The relationships between the above variables and the adopted model proposed by Amin et al, (2014) are depicted in Figure 4.

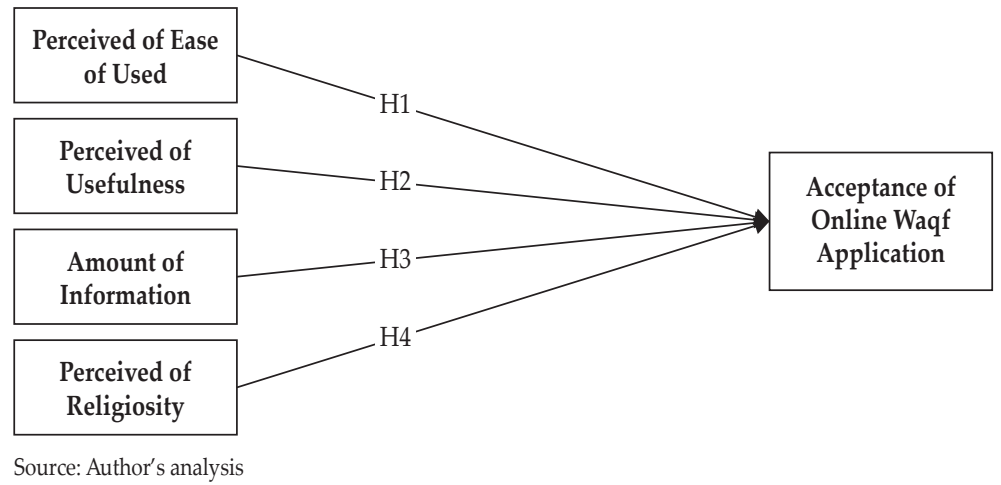

Figure 4 .

Proposed Research Model

\subsection{Method}

The data were processed and analysed after all the responses had been gathered. We used SPSS, AMOS and STATA software for the calculation. To ensure all the data were suitable for use, validity and reliability testing was conducted using SPSS ; then, to test the model and hypothesis, a regression test was performed using SEM with AMOS software. 


\subsubsection{Descriptive Analysis}

In the following descriptive analysis, the respondents' profiles from the online questionnaire previously distributed will be interpreted. The information relates to gender, education, job, income, project preference and percentage of income used for charity.

\subsubsection{Validity and Reliability Test}

Validity demonstrates the degree to which an estimation tool is suitable for estimating what requires to be measured. A research instrument must pass a validity test to ensure that it can be used to generate valid results. Another type of test is a reliability test, which is used to measure the consistency of the instrument used. This test can be done in the external and internal analysis. With regard to external reliability, tests include test-retest of the instrument, equivalent, and a combination of both methods. On the other hand, the internal analysis test is Cronbach's alpha, as proposed by Sekaran (2003). In this research, an internal reliability test was conducted to measure the consistency of the responses. (Sekaran, 2003)

Confirmatory factor analysis (CFA) was also employed as a measurement model to show how the observed variable can interpret some measured item by examining convergent validity and reliability. Convergent validity can quantify the connection of every factor in the model. A convergent validity test using the SPSS program can be interpreted by the factor loading value of variables which are at one point. The rule used to assess convergent validity is that the factor loading value should be $>0.50$; the goal of such factor loading is to measure the average value of variance for validity. The AVE score should be $>0.50$ (Jabeen, Yan, Ahmad, Fatima, \& Qamar, 2019):

$$
A V E=\frac{\sum \lambda_{i}^{2}}{\sum \lambda_{i}^{2}+\sum_{i} \operatorname{var}\left(\varepsilon_{i}\right)}
$$

where

$\lambda_{i}$ is factor loading

Var is variance

$\varepsilon_{i}$ is error variance

The reliability test will be measured using Cronbach's alpha (Sekaran, 2003) and composite reliability (Jabeen et al., 2019); both cut-off values are $>0.70$. SPSS also enables measurement of composite reliability.

$$
C R=\frac{\left(\sum \lambda_{i}\right)^{2}}{\left(\sum \lambda_{i}\right)^{2}+\left(\sum \epsilon_{i}\right)}
$$


where:

$\lambda_{i}$ is factor loading

Var is variance

$\varepsilon_{i}$ is error variance

The cut-off value for validity and the reliability parameter is shown in Table 2.

Table 2.

Validity and Reliability Parameter

\begin{tabular}{lcc}
\hline Validity and Reliability & Parameter & Cutoff Value \\
\hline \multirow{2}{*}{ Convergent Validity } & Factor Loading & $>0.50$ \\
& Average Variance Extracted (AVE) & $>0.50$ \\
\hline \multirow{2}{*}{ Reliability } & Cronbach's Alpha & $>0.70$ \\
& Composite Reliability & $>0.70$ \\
\hline
\end{tabular}

(Source: Waluyo, 2016 ; Jabeen et al., 2019)

\subsubsection{Structural Equation Modeling}

Structural Equation Modeling (SEM) is a statistical technique that simultaneously solves multilevel models that cannot be solved through linear regression equations. In general, SEM is used when research variables are latent or when they cannot be directly measured, but only through indicators. It can be used to fix the equation model with more than one dependent variable emphasising mutual or recursive influence. The data were analysed using the maximum likelihood (ML) technique; hence, several assumptions needed to be completed, namely sample size, normality evaluation and the goodness of fit test.

Sample size plays a crucial role in SEM outcome interpretation, and provides the foundation for estimating sampling error. Using the assessment model Maximum Likelihood (ML), the minimum sample required is 150. ML can generate a decent (unbiased) parameter estimate if the information used is consistent with this assumption. Under the assumption of a multivariate normal distribution of the observed variables, maximum likelihood estimators have the desirable asymptotic, or large-sample, properties of being unbiased, consistent and efficient (Anderson \& Gerbing, 1988)

Normality assessment is made using the CR skewness and CR kurtosis of the data. It is split into two phases: univariate normality, which measures each variable's normality, and multivariate normality, which simultaneously tests the normality. Both CR skewness and kurtosis have a cut-off value of $\pm \leq 2.58$. (Arbuckle, 2013).

The goodness of fit model function is to compare models indicated with covariance matrices between indices or observed variables. If the model is above the cut-off value, it is acceptable; however, if it is not approved, it should be altered. There are three goodness regarding fit indices, namely absolute fit indices, incremental fit indices, and indices of parsimony fit; each index contains several components (Arbuckle, 2013). This research does not require an empirical study to fulfil and report all the GOF indices, so only two indices (with nine measurement elements included) were used. 
First, to compare compatibility between the suggested model and the recorded information, absolute fit indices were employed. These consist of chi-square, probability, RMSEA (root mean square error approximation), GFI (goodness of fit indices), and CMIN/DF. Second, to compare the model suggested in the study with the baseline model, frequently referred to as the null model, incremental fit indices were used, which consist of AGFI (adjusted goodness of fit), TLI (Tucker Lewis index), and CFI (comparative fit index). The value of the indices can be seen in Table 3.

Table 3.

Goodness of Fit Index Value of Proposed Model

\begin{tabular}{lcc}
\hline No. & Goodness of Fit Index & Cutoff Value \\
\hline 1. & DF & Positive \\
2. & RMSEA & $\leq 0.08$ \\
3. & GFI & $>0.90$ \\
4. & AGFI & $\geq 0.90$ \\
5. & CMIN/DF & $\leq 5.00$ \\
6. & TLI & $>0.90$ \\
7. & CFI & $>0.90 ;>0.95$ \\
\hline
\end{tabular}

(Source: Authors' analysis)

The most common fit metric is RMSEA, initially called RMS, and used by SEM scientists as the sample size does not overestimate or underestimate the RMSEA value. RMSEA measures the deviation with its population covariance matrix of a model's parameter values. An RMSEA value average of 0.08 shows that the fit model is good enough, as stated by Waluyo (2016). An RMSEA value of around 0.08 or lower indicates a reasonable error of approximation, so a model with RMSEA greater than 0.1 will not be utilised (Arbuckle, 2013).

GFI is a fit index criterion which measures the overall suitability of the model calculated from the predicted quadratic residual model compared to actual observational data. The value of GFI is $0-1$; the higher the value, the better the specification of the model. The cut-off GFI value as a fit model size is $>0.90$. AGFI is a GFI design adapted for a suggested model with a degree of freedom for a null model. For the model fit indication, the cut-off value of AGFI is $>0.90$ (Arbuckle, 2013).

CMIN/DF is a measure obtained from the chi-square value divided by the degree of freedom, often called the normal chi-square. Acceptable values for CMIN/DF are $\leq 5$. To compare models tested with the baseline model, TLI, often referred to as rho2, is used in this research. This is one of the fit indexes that is not affected by the sample size. For the model fit indication, the recommended TLI value is $>0.90$. CFI is another null model hypothesised relative metric. The suggested value of CFI is $>0.90$ or $>0.95$, based on Arbuckle (2013). 


\subsubsection{Hypothesis Testing}

The final step in data processing is testing the hypotheses. The next phase is the causal analysis of each variable in the structural model (hypothesis testing). The value of the regression weights indicates the relationship between the variables in the hypothesis. Hypothesis testing analyses the level of significance of the causal relationship in the model based on the probability value, $\mathrm{p}<0.05$; in addition, the Cr of each relation is $>2.00$, also based on Arbuckle (2013).

\section{RESULTS AND ANALYSIS}

\subsection{Results}

\subsubsection{Descriptive Statistics}

The data collected were 253 . The respondents' profile consisted of gender, education, age, job, income, and the percentage of income used for charity. The details are shown in Figure 5.

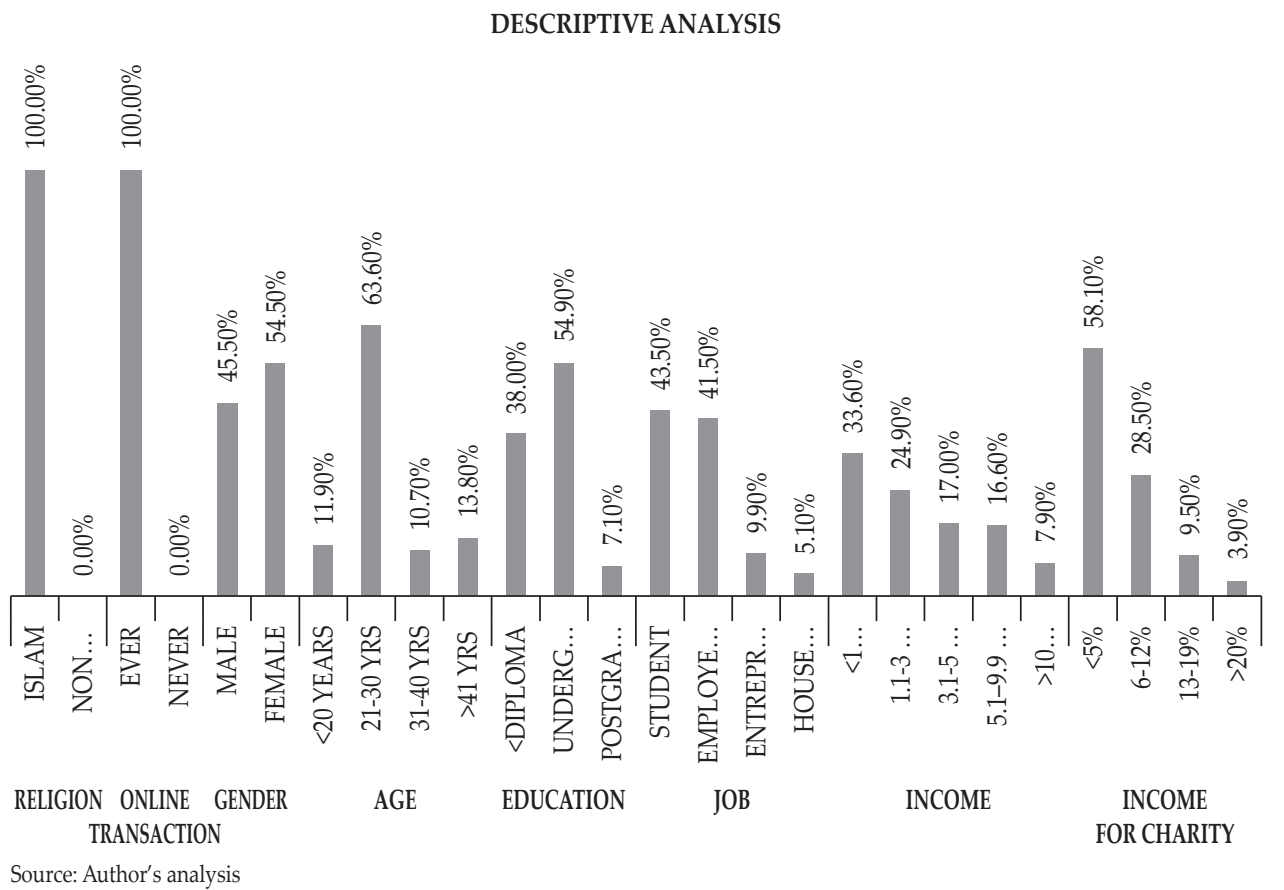

Figure 5 .

Descriptive Analysis

\subsubsection{Measurement Results for the Proposed Model}

The measurement result and structural model for the proposed model is presented in Figure 6 below. 


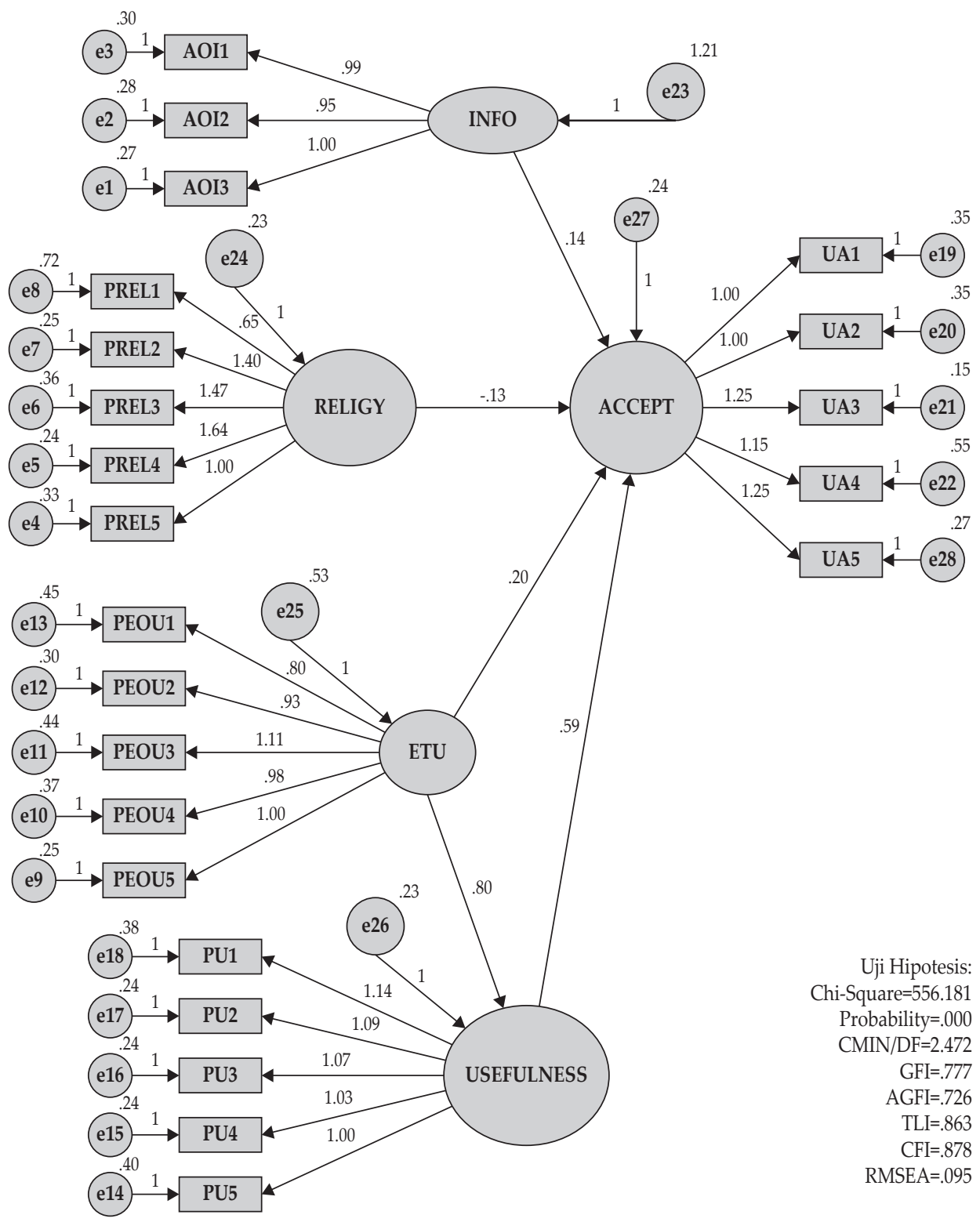

Note: AOI = Amount of Information, PREL = Perceived Religiosity; ETU = Easy to Use; PEOU = Perceived Ease of Use, $\mathrm{PU}=$ Perceived Usefulness, UA = User Acceptance of Waqf Application

Source: Author's analysis

Figure 6.

Structural Equation Model for the Proposed Model

The results show that out of the nine indicators, only two met the required cut-off value, namely degree of freedom and CMIN/DF. Based on these results, the proposed model was not fit and needed to be modified. The modified model is shown in Figure 7. 


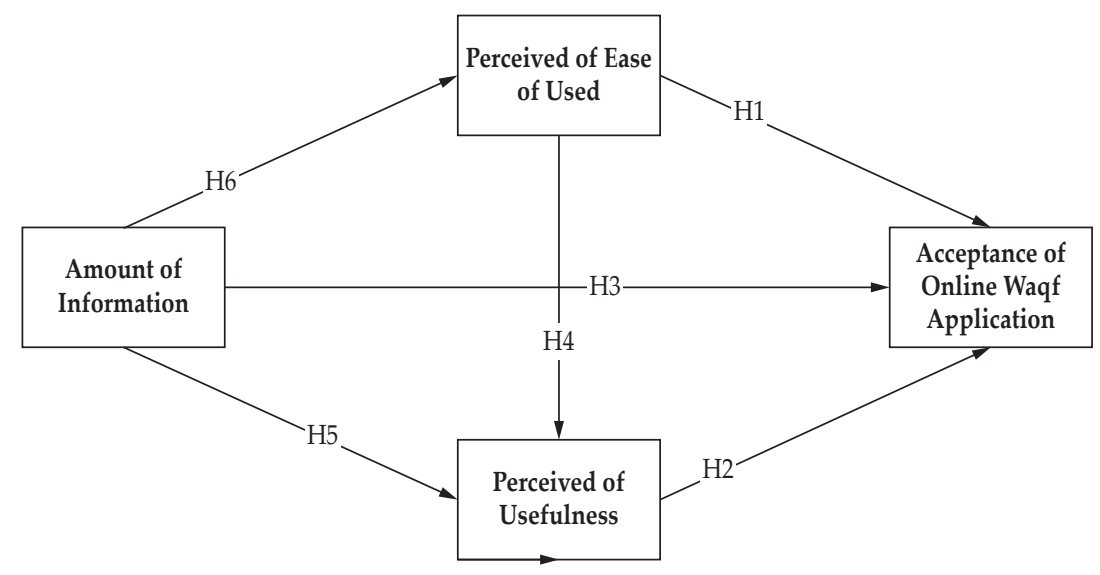

Source: Author's analysis

Figure 7 . Modified Model

The new modified research model was used for the analysis. Several items were still available from the previous research, such as the relationships between perceived ease of use and acceptance; perceived usefulness and acceptance; the amount of information and acceptance; and the relationship between perceived ease of use and perceived usefulness. Furthermore, several hypotheses were added, such as the relationship between the amount of information and acceptance, which is now $\mathrm{H} 3$, and perceived ease of use and usefulness, which is now $\mathrm{H} 4$.

A new hypothesis is included in the new model, namely the relationship between the amount of information and perceived usefulness. This is based on the research of Cho and Sagynov (2015), who found such a positive relationship. In consequence, this research also intends to establish if this relationship is implemented in online waqf application acceptance. (Cho \& Sagynov, 2015)

H5: The amount of information influences perceived usefulness.

Another new hypothesis that is included in the new model concerns the relationship between the amount of information and perceived ease of use. Kumar, Smith, and Bannerjee (2004) found that the amount of information did influence perceived ease of use. Therefore, this research also intends to ascertain if this relationship is implemented in online waqf acceptance.

H6: The amount of information influences perceived ease of use.

\subsubsection{Validity and Reliability Test}

To measure validity and reliability, the research used factor loading, average variance extracted, composite reliability, and Cronbach's alpha. The results are shown in Table 4. 
Table 4.

Measurement Model Results

\begin{tabular}{|c|c|c|c|c|c|}
\hline $\begin{array}{l}\text { Model } \\
\text { Construct }\end{array}$ & $\begin{array}{l}\text { Measurement Item } \\
\text { Indicator }\end{array}$ & $\begin{array}{l}\text { Standard } \\
\text { Loading }\end{array}$ & AVE & $\begin{array}{l}\text { Construct } \\
\text { Reliability }\end{array}$ & $\begin{array}{c}\text { Cronbach } \\
\text { Alpha }\end{array}$ \\
\hline \multirow[t]{3}{*}{$\mathrm{PU}$} & PU1 & 0.790 & \multirow{3}{*}{0.715} & \multirow{3}{*}{0.882} & \multirow{3}{*}{0.875} \\
\hline & PU2 & 0.908 & & & \\
\hline & PU3 (PU4) & 0.834 & & & \\
\hline \multirow[t]{3}{*}{ PEOU } & PEOU1 (PEOU2) & 0.665 & \multirow{3}{*}{0.601} & \multirow{3}{*}{0.817} & \multirow{3}{*}{0.816} \\
\hline & PEOU2 (PEOU4) & 0.826 & & & \\
\hline & PEOU3 (PEOU5) & 0.824 & & & \\
\hline \multirow[t]{3}{*}{$\mathrm{AOI}$} & AOI1 & 0.895 & \multirow{3}{*}{0.807} & \multirow{3}{*}{0.926} & \multirow{3}{*}{0.926} \\
\hline & AOI2 & 0.901 & & & \\
\hline & $\mathrm{AOI} 3$ & 0.899 & & & \\
\hline \multirow[t]{3}{*}{ UAWA } & UAWA1 (UAWA2) & 0.793 & \multirow{3}{*}{0.757} & \multirow{3}{*}{0.903} & \multirow{3}{*}{0.901} \\
\hline & UAWA2 (UAWA3) & 0.944 & & & \\
\hline & UAWA3 (UAWA5) & 0.866 & & & \\
\hline
\end{tabular}

Note: PU = Perceived Usefulness, PEOU = Perceived Ease of Use, AOI = Amount of Information, UAWA = User Acceptance of Waqf Application

Source: Author's analysis

Based on Table 4, the standard loading value is $>0.5$, which meets the requirement. The proportion of AVE between the items or indices of a structure in the confirmatory factor assessment is a summary of the convergent indicator. AVE $>0.50$ shows acceptable convergence. Table 4 indicates that all the AVEs of each variable are $>0.50$. Furthermore, all the variables used in this model are valid.

With regard to reliability, two measurements can be employed, namely construct reliability and Cronbach's alpha, both of which should be $>0.60$. Table 4 shows that for all the variables, the construct reliability and Cronbach's alpha scores are $>0.70$. Furthermore, the variables used in the model are reliable.

\subsubsection{Assessment of Normality}

AMOS software is used by scientists to assist with data normality testing. The outcome can interpret normality output evaluation. The cut-off value frequently used to evaluate normality is the critical proportion of the value of both CR skew and CR kurtosis, which should be $\pm \leq 2.58$ (Waluyo, 2016). Details of the normality test for the modified model are presented in Table 5. 
Table 5.

Normality Test for the Modified Model

\begin{tabular}{lcccccc}
\hline Variable & min & max & skew & c.r. & kurtosis & c.r. \\
\hline Q12 & 1.000 & 5.000 & -.677 & -3.539 & -.398 & -1.040 \\
Q11 & 1.000 & 5.000 & -.579 & -3.025 & -.512 & -1.337 \\
Q10 & 1.000 & 5.000 & -.194 & -1.013 & -.517 & -1.351 \\
Q4 & 1.000 & 5.000 & -.707 & -3.695 & .027 & .071 \\
Q5 & 1.000 & 5.000 & -.615 & -3.213 & -.298 & -.779 \\
Q6 & 2.000 & 5.000 & -.341 & -1.780 & -.884 & -2.310 \\
Q1 & 1.000 & 5.000 & -.951 & -4.971 & .172 & .450 \\
Q2 & 1.000 & 5.000 & -1.296 & -6.774 & 1.269 & 3.317 \\
Q3 & 1.000 & 5.000 & -1.371 & -7.167 & 1.166 & 3.047 \\
Q7 & 1.000 & 5.000 & -.185 & -.970 & -.873 & -2.282 \\
Q8 & 1.000 & 5.000 & -.185 & -.967 & -.668 & -1.747 \\
Q9 & 1.000 & 5.000 & -.157 & -.823 & -.906 & -2.368 \\
Multivariate & & & & & 69.803 & 24.384 \\
\hline
\end{tabular}

Source: Author's analysis

According to the above data, almost none of the values of $\mathrm{Cr}$ skewness and $\mathrm{Cr}$ Kurtosis meet the requirements of the normality test. Furthermore, the data are not normal. However, AMOS provides a tool that can be used to alternate the normality results by using bootstrapping; in this research, the Bollen-Stine technique was used for this. The technique estimates the chi-square and creates a confidence interval. Table 6 shows the bootstrap distribution of the model.

Table 6.

Bootstrap Distribution

\begin{tabular}{|c|c|c|}
\hline & & | -------------------- \\
\hline & 23.963 & |* \\
\hline & 32.352 & $\left.\right|^{* *}$ \\
\hline & 40.741 & $\mid * * * * * * * *$ \\
\hline & 49.130 & $\mid * * * * * * * * * * * *$ \\
\hline & 57.519 & $\mid * * * * * * * * * * * *$ \\
\hline & 65.908 & $1 * * * * * * * * * * * * * * * *$ \\
\hline & 74.297 & $\mid * * * * * * * * * * * *$ \\
\hline$N=164$ & 82.686 & |******** \\
\hline Mean $=67.344$ & 91.075 & |***** \\
\hline \multirow[t]{7}{*}{ S.E. $=1.566 \mathrm{P}=0.343$} & 99.463 & $\left.\right|^{* *}$ \\
\hline & 107.852 & |*** \\
\hline & 116.241 & $\left.\right|^{* *}$ \\
\hline & 124.630 & | \\
\hline & 133.019 & |* \\
\hline & 141.408 & |* \\
\hline & & | --------------------- \\
\hline
\end{tabular}

Source: Author's analysis 
Based on Bollen-Stein probability, if the probability is $\geq 0.05$, the model will be correct. In this model it is 0.343 , which means that it is correct.

\subsubsection{Goodness of Fit Results}

The goodness of fit results for the modified model can be seen in Table 7.

Table 7.

Goodness of Fit Model Results

\begin{tabular}{lccc}
\hline Goodness of Fit Index & Cut-off Value & Modified Model & Analysis \\
\hline Chi-Squares & Smaller & 72.41 & Acceptable \\
Probability & $\geq 0.05$ & 0.013 & Unacceptable \\
DF & Positive & 48 & Acceptable \\
RMSEA & $\leq 0.08$ & 0.056 & Acceptable \\
GFI & $>0.90$ & 0.932 & Acceptable \\
AGFI & $\geq 0.90$ & 0.890 & Marginal \\
CMIN/DF & $\leq 5.00$ & 1.509 & Acceptable \\
TLI & $>0.90$ & 0.976 & Acceptable \\
CFI & $>0.90 ;>0.95$ & 0.983 & Acceptable \\
\hline
\end{tabular}

Source: Author's analysis

Table 7 shows the results of the goodness of fit model calculations. The research used two types of goodness of fit model analysis, absolute best fit and incremental goodness fit. The indicators of absolute goodness fit are chi-square, probability, df and RMSEA. Degree of freedom and RMSEA in the modified model are accepted because they pass the requirements. Based on the Bollen-Stein results, although probability and chi-square are still not good, the model is still acceptable.

In the incremental analysis, the factors are GFI, AGFI, CMIN/DF, TLI and CFI. All the factors for the modified model used in the incremental goodness fit are acceptable. GFI is higher than $>0.90$, while AGFI is also higher than $>0.90$ and better than the purposed model score. CMIN/DF is $<5.0$, and the TLI and CFI scores are also higher than $>0.90$. Based on these results, the modified research model used is fit and acceptable for use to measure user acceptance of online waqf application.

\subsubsection{Structural Model}

Following acceptance of all the goodness-of-fit indicators, the next stage was to assess the structural model relationship (hypothesis testing). The regression weight shows the relationship between factors, as shown in Table 8. Hypothesis testing analyses the level of significance of causal relationship of each variable in the model proposed. 
Table 8.

Regression Weight

\begin{tabular}{lccccc}
\hline Causal Path & Hypothesis & Coefficient & C.R. & P & Supported \\
\hline PEOU $\rightarrow$ UAWA & H1 & .404 & 3.141 & .002 & Yes \\
PU $\rightarrow$ UAWA & H2 & .420 & 3.829 & .000 & Yes \\
AOI $\rightarrow$ UAWA & H3 & .087 & 1.777 & .076 & No \\
AOI $\rightarrow$ PEOU & H4 & .330 & 5.830 & .000 & Yes \\
PEOU $\rightarrow$ PU & H5 & .794 & 7.406 & .000 & Yes \\
AOI $\rightarrow$ PU & H6 & -.001 & -.021 & .983 & No \\
\hline
\end{tabular}

Note: PU = Perceived Usefulness, PEOU = Perceived Ease of Use, AOI = Amount of Information, UAWA = User Acceptance of Waqf Application, C.R = Critical Ratio

Notes: $\mathrm{P}<0.05^{*} ; \mathrm{P}<0.01^{* *} ; \mathrm{P}<0.001^{* * *}$ (Waluyo, 2016).

Source: Author's analysis

Table 8 shows the regression results of the model. We find that amount of information has a statistically significant influence on perceived ease of use because the C.R. is $>2.00$ and the p-value is $<0.05$. Furthermore, perceived ease of use influences both perceived usefulness $(C . R=7.406$ and $p$-Value $=0.000)$ and user acceptance of online waqf application $(C \cdot R=3.141$ and $p$-value $=0.002)$. Moreover, user acceptance is also influenced by perceived usefulness (C.R. $=3.829$ and $p$-value $=0.000$ ). On the other hand, amount of information has no statistically significant relationships with perceived usefulness or user acceptance of waqf application. The structural equation model is presented in Figure 8.

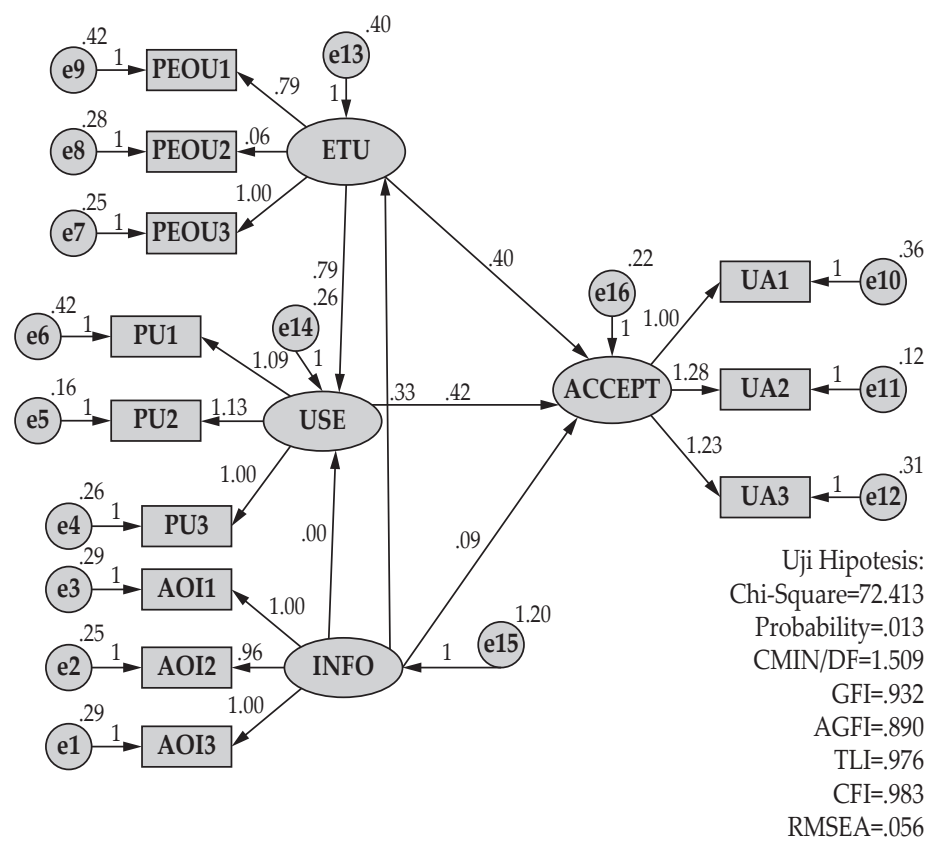

Note: $\mathrm{ETU}=$ Easy to Use; $\mathrm{PEOU}=$ Perceived Ease of Use; USE = Usefulness, PU = Perceived Usefulness, AOI = Amount of Information, UA = User Acceptance of Waqf Application

Source: Author's analysis

Figure 8.

Structural Equation Model for the Modified Model 


\subsection{Robustness Test}

For the robustness test, we conducted multilinear regression for both the basic and modified model. The results, as shown in Tables 9 and 10, are consistent with the SEM results. For the basic model, perceived usefulness and amount of information have a positive significant relationship with behavioural acceptance at the $95 \%$ confidence level, while perceived ease of use is significant at the $90 \%$ confidence level. Consistent with SEM, perceived religiosity has no statistically significant relationship with behavioural acceptance.

Table 9.

Robustness Test for the Basic Model

\begin{tabular}{lcccc}
\hline Variable & Coefficient & Std. Err & t-Stat & p-value \\
\hline Perceived Usefulness & 0.6327 & 0.0681 & 9.29 & 0.000 \\
Perceived Ease of Use & 0.1288 & 0.0743 & 1.74 & 0.084 \\
Perceived Religiosity & 0.0342 & 0.0689 & 0.50 & 0.620 \\
Amount of Information & 0.2768 & 0.0664 & 4.17 & 0.00 \\
Const & -0.6317 & 1.4153 & -0.04 & 0.964 \\
Number of Observations & & & \multicolumn{2}{c}{253} \\
F-Stat & & & \multicolumn{2}{c}{76.07} \\
Prob $>$ F & & & \multicolumn{2}{c}{0.000} \\
R-Square & & & \multicolumn{2}{c}{0.5510} \\
Adjst R.Square & & & & \\
\hline
\end{tabular}

For the modified model, all three independent variables have a positive significant relationship with behavioural acceptance at the 95\% confidence level, as shown in Table 10.

Table 10.

Robustness Test for the Modified Model

\begin{tabular}{lcccc}
\hline Variable & Coefficient & Std. Err & t-Stat & p-value \\
\hline Perceived Usefulness & 0.5781 & 0.0669 & 8.64 & 0.000 \\
Perceived Ease of Use & 0.1906 & 0.0740 & 2.58 & 0.011 \\
Amount of Information & 0.1908 & 0.0418 & 4.57 & 0.00 \\
Const & -0.0208 & 0.7065 & -0.03 & 0.977 \\
Number of Observations & & & \multicolumn{2}{c}{253} \\
F-Stat & & & \multicolumn{2}{c}{93.17} \\
Prob > F & & & \multicolumn{2}{c}{0.000} \\
R-Square & & & \multicolumn{2}{c}{0.5289} \\
Adjst R.Square & & & & 0.5232 \\
\hline
\end{tabular}

Source: Researchers' data analysis

\subsection{Analysis}

The purpose of this research was to establish the factors related to user acceptance of online waqf application. The TAM concept was employed to develop the research model. Five variables were observed in the research, and five hypotheses 
analysed. In the process, the model was modified to four observed variables, with six hypotheses. A summary of the hypothesis results is presented in Table 11.

Table 11.

Hypothesis Results

\begin{tabular}{lcc}
\hline Hypothesis & Relation & Status \\
\hline H1 & PEOU $\rightarrow$ UAWA & Accepted \\
H2 & PU $\rightarrow$ UAWA & Accepted \\
H3 & AOI $\rightarrow$ UAWA & Rejected \\
H4 & PEOU $\rightarrow$ PU & Accepted \\
H5 & AOI $\rightarrow$ PU & Rejected \\
H6 & AOI $\rightarrow$ PEOU & Accepted \\
H3 Previous Model & PREL $\rightarrow$ UAWA & Rejected \\
\hline
\end{tabular}

Note: PU = Perceived Usefulness, PEOU = Perceived Ease of Use, AOI = Amount of Information, UA = User Acceptance of Waqf Application

Source: Researchers ' data analysis

\section{Hypothesis 1: Perceived ease of use influences user acceptance - Accepted}

Based on the hypothesis testing, perceived ease of use influences user acceptance. This finding is consistent with those of Ramayah et al. (2003) in their research on the acceptance of internet banking by Malaysian consumers, who found that there was a positive relationship between perceived ease of use and user acceptance. Pikkarainen et al. (2004) also found a similar relationship in their research on consumer acceptance of online banking.(Ramayah et al., 2003) Hypothesis 2: Perceived usefulness influences user acceptance - Accepted

Amin et al. (2014) and Tang and Chiang (2009) found that there was a positive relationship between perceived usefulness and user acceptance, in line with this research. The results of the hypothesis testing show that perceived usefulness influences user acceptance of online waqf application.

\section{Hypothesis 3: Amount of information does not influence user acceptance -} Rejected

Based on Amin et al. (2014), the amount of information has a positive relationship with user acceptance. However, from the hypothesis testing results of this research, the amount of information does not influence user acceptance. When users accept online waqf application, one variable that influences this is perceived usefulness. Based on the hypothesis testing, the amount of information does not influence user acceptance directly, while the variable influences perceived ease of use, which directly influences perceived usefulness. Therefore, the amount of information is still essential for users to accept online waqf application Hypothesis 4: Perceived ease of use influences erceived usefulness - Accepted

Based on the research of Amin (2007), perceived ease of use influences perceived usefulness. Suhud et al. (2019) also found the same relationship with regard to online waqf application. This relates to the previous hypothesis proposing that perceived ease of use does not influence user acceptance directly, but does influence perceived usefulness, which in turn influences user acceptance directly. 


\section{Hypothesis 5: The amount of information influences perceived usefulness - Rejected}

Cho et al. (2015) found that there was a positive relationship between the amount of information and perceived usefulness. However, based on our hypothesis testing, the amount of information does not influence perceived usefulness. In online waqf application, information about the application influences its ease of use. Therefore, when users have enough information about online waqf, this directly influences their perceived ease of use of the application, and this variable will influence its perceived usefulness.

\section{Hypothesis 6: The amount of information influences perceived ease of use - Accepted}

Kumar et al. (2004) found that the amount of information influenced the perceived ease of use; our hypothesis testing came to the same conclusion. This result is relevant to the previous hypothesis, that the amount of information does not influence the perceived usefulness of online waqf application. The information users have can influence them in their use and understanding of the online waqf application. This ease in using the application can affect users .

Hypothesis 3 from the previous model: Perceived religiosity does not influence user acceptance - Rejected

Mokhlis (2009) states that religiosity is a relevant variable that can be used in marketing research, especially that which relates to behaviour. Ahmad et al. (2008) also found that religion was a factor that influenced people's choice of bank. Moreover, religiosity is also a factor that influences people when choosing products provided by banks to their customers. (Safiek Mokhlis, 2009)

In the proposed model, religion does not influence user acceptance of online waqf application, but is a factor that determines user acceptance and waqf related to Muslims. However, in Indonesia religion is not an influencing factor if it relates to caring for others. This is in line with Wulandari and Subagio's (2015) findings that customers in Jember (Indonesia) gave more consideration to the different facilities and services of Bank Muamalat (an Islamic bank) and Bank BRI (a nonIslamic bank) than to religious reasons before making decisions.

If we relate the demography of respondents with their adoption of online waqf application, $65 \%$ of female and $64 \%$ of males that agree or highly agree about using online waqf. As regards income level, respondents with an income of 5.1 million -7 million rupiahs represented the highest percentage of online waqf application use $(71.9 \%)$ compared to the 7.1 million -9.9 million category $(70 \%), 1.1$ million -3 million category $(69.8 \%)$, more than 10 million category (55\%), and 3.1 million - 5 million category (53.5\%). Regarding employment, housespouses constituted the highest percentage $(76.9 \%)$, followed by entrepreneurs $(72 \%)$, students $(69.1 \%)$, and employees/professionals (57.1\%)

In relation to the age category, the 21 to 30 group has the highest percentage of online waqf application use $(68.3 \%)$, followed by the 31 to 40 category $(66.7 \%)$, $<20$ years $(60 \%)$, and $>40$ years $(51.4 \%)$. Finally, in the education category, undergraduates had the highest percentage of online waqf application use $(67.6 \%)$, followed by diploma and below (63.5\%), and postgraduates (56.3\%). 


\section{CONCLUSION AND RECOMMENDATIONS}

\subsection{Conclusion}

The research has found that the variables that directly influence user acceptance are perceived ease of use and perceived usefulness. In addition, the amount of information influences user acceptance of online waqf application indirectly. Furthermore, the amount of information influences perceived ease of use, and in turn perceived ease of use influences perceived usefulness before it directly influences user acceptance. The study has also found that perceived religiosity is an insignificant variable in the case of Indonesia online waqf application. The study fills the gap in the literature concerning the context of the technology acceptance model of online waqf application in Indonesia.

\subsection{Recommendations}

\subsubsection{Recommendations for Application Providers}

The outcome of this study is that two factors affect user recognition when using online waqf application, namely perceived usefulness and the amount of information. Online waqf providers should provide practical applications to make online waqf. They could add certain features to enhance usefulness, as the application could include other charity activity in addition to waqf. Besides, the application could handle charity budgets and other enhancements to boost its use.

There is also a connection between perceived ease of use and perceived usefulness based on the study results. Provider could optimise this relationship by producing enhancements to the application. To make the application more comfortable to use, developers could create the application's UI / UX layout more readily, and make it easier to use. When the application's characteristics are being updated, it should be ensured that the update is notified and the new function is introduced to customers. Accordingly, it will be possible to use the new function more effectively.

The amount of information is another variable that affects users' intentions, and this also affects perceived ease of use. Developers need to ensure that the information variable is well-fulfilled for the user . Information should be readily accessed by users today. For online waqf providers, the organisations should actively provide information about the online waqf application they employ by using direct or indirect media, in particular information on how to use it, how to get it, and what features the application includes.

Another aspect to consider is how to update the application and obtain helpful evaluation from the App Store or Play Store. The last issue to consider is to provide a manual or tutorial with the app on how to conduct waqf online.

In the project preference analysis, the research found the four most selected projects by respondents based on the questionnaire results, these being mosque construction, Islamic boarding school construction, school construction, and hospital construction. Therefore, application developers and Nazhir could consider providing these projects in their application and services. For the most popular projects, funds could be collected more quickly and the project finished faster and used by more people. 


\subsubsection{Recommendations for Regulators}

To increase user acceptance, online waqf developers should provide more information about their apps and develop more user-friendly ones with enhanced features. Furthermore, regulators should provide incentives for online waqf developers to maximise cash waqf collection.

5.2.3. Recommendations for Future Research

In the scope of the research, several limitations have arisen, which could be input for improvements in future research. First, researchers could use more samples for analysis. If many samples are used the population can be interpreted better, especially if the aim is to analyse Indonesia people. Second, in defining the sampling method, it could be useful not to employ convenience sampling, as this tends to be biased. Another sampling method could be utilised to ensure the results are not biased and contain errors. Third, future research should define where the sample comes from, so that the distribution of the sample region can be seen. Fourth, more external variables could be examined to determine user acceptance. Fifth, the respondents' understanding of the difference between infaq, waqf, alms, and zakat should be addressed. Finally, specific research regarding a brand that provides online waqf application need to be conducted ; in this way, researchers will also be able to interpret the performance of specific developers.

\section{REFERENCES}

Amin, H. (2007). Journal of Internet Banking and Commerce Internet Banking Adoption Among Young Intellectuals. Journal of Internet Banking and Commerce, 12(3). Retrieved from http://www.arraydev.com/commerce/jibc/

Amin, H., Rahim, A., Ramayah, T., \& Supinah, R. (2014). Determinants of Online Waqf Acceptance : An Empirical Investigation. Journal of Information Systems in Developing Countries, 60(8), 1-18. https://doi.org/10.1002/j.1681-4835.2014. tb00429.x

Anderson, J. C., \& Gerbing, D. W. (1988). Structural Equation Modeling in Practice : A Review and Recommended Two-Step Approach. Psychological Bulletin, 103(3), 411-423.

Arbuckle, J. L. (2013). IBM SPSS Amos 22 User's Guide.

Asosiasi Penyelenggara Jasa Internet Indonesia, 2018, Penetrasi \& Perilaku Pengguna Internet Indonesia 2017, . Viewed 3rd July 2019 at https://www.apjii. or.id/content/read/39/342/Hasil-Survei-Penetrasi-dan-Perilaku-PenggunaInternet-Indonesia-2017

Badan Wakaf Indonesia, n.d Jenis Harta Wakaf. Viewed 30 th May, 2019 at https://bwi. or.id/index.php/en/tentang-wakaf/mengenal-wakaf/jenis-harta-benda-wakaf. html

Badan Wakaf Indonesia, n.d. Unsur-Unsur Wakaf. Viewed 30 th May, 2019 at https:// bwi.or.id/index.php/en/tentang-wakaf/mengenal-wakaf/syarat-a-rukunwakaf.html

Badan Wakaf Indonesia, n.d. Data Tanah Wakaf Seluruh Indonesia. Viewed 30 ${ }^{\text {th }}$ May, 2019 at https://bwi.or.id/index.php/en/tentang-wakaf/data-wakaf/data-wakaftanah.html 
Badan Wakaf Indonesia, n.d. Regulasi Wakaf. Viewed 30 th May, 2019 at https://bwi. or.id/index.php/en/regulasi/regulasi-wakaf.html

Cho, Y. C., \& Sagynov, E. (2015). Exploring Factors That Affect Usefulness, Ease Of Use, Trust, And Purchase Intention In The Online Environment. International Journal of Management \& Information Systems, 19(1).

Chuttur, M. (2009). Overview of the Technology Acceptance Model: Origins, Developments and Future Directions. Working Papers on Infomation Systems, 9-37.

Darus, F., Huda, N., Shukri, A., Yusoff, H., Ramli, A., Zain, M. M., ... Bakar, A. (2017). Empowering Social Responsibility of Islamic Organizations through Waqf. Research in International Business and Finance, 42, 959-965. https:/doi. org/10.1016/j.ribaf.2017.07.030

Davis, F. D. (1989). Perceived Usefulness, Perceived Ease of Use. Management Information Systems Research Center, University of Minnesota, 319-240.

Davis, F. D., Bagozzi, R. P., \& Warshaw, P. R. (1989). User Acceptance of Computer Technology : A Comparison of Two Theoretical Models. Management Science, 35(8), 982-1103.

Dewan Perwakilan Rakyat Republik Indonesia, 2004, Undang-Undang Tentang Wakaf, Viewed 1st July 2019 at https://jdih.kemenkeu.go.id/ fulltext/2004/41TAHUN2004UU.htm

Fadhilah, \& Nur, U. (2018). Potensi Wakaf Tunai Capai Rp 180 Triliun. Retrieved November 22, 2019, from Republika.co.id website: https://www.republika. co.id/berita/dunia-islam/wakaf/18/10/16/pgovmd384-potensi-wakaf-tunaicapai-rp-180-triliun

Hair, J. F., Black, W. C., Babin, B. J., \& Anderson, R. E. (2014). Multivariate Data Analysis (MVDA). In Pharmaceutical Quality by Design: A Practical Approach (7th ed.). https://doi.org/10.1002/9781118895238.ch8

Jabeen, G., Yan, Q., Ahmad, M., Fatima, N., \& Qamar, S. (2019). Consumers' Intention-based Influence Factors of Renewable Power Generation Technology Utilization: a Structural Equation Modeling Approach. Journal of Cleaner Production, 237. https://doi.org/10.1016/j.jclepro.2019.117737

Kahf, M. (2003). The Role of Waqf in Improving the Ummah Welfare.

Kumar, R. L., Alan, M., \& Bannerjee, S. (2004). User Interface Features Influencing Overall Ease of Use and Personalization. Information $\mathcal{E}$ Management, 41, 289302. https://doi.org/10.1016/S0378-7206(03)00075-2

Majelis Ulama Indonesia, 2002, Keputusan Fatwa Majelis Ulama Indonesia Mengenai Wakaf Uang, Viewed at 1st July 2019 at http://mui.or.id/wp-content/ uploads/files/fatwa/29.-Wakaf-Uang.pdf

Masrikhan, M. (2019). Optimalisasi Potensi Wakaf Di Era Digital Melalui Platform Online Wakafin.com Dengan Konsep Crowdfunding Sebagai Penggerak Ekonomi Masyarakat. Jurnal Ekonomi Syariah, 1, 1-12.

Mohsin, M. I. A. (2013). Financing Through Cash-waqf: a Revitalization to Finance Different Needs. International Journal of Islamic and Middle Eastern Finance and Management, 6(4), 304-321. https://doi.org/10.1108/IMEFM-08-2013-0094 
Pikkarainen, T., Pikkarainen, K., Karjaluoto, H., \& Pahnila, S. (2004). Consumer Acceptance of Online Banking: An Extension of the Technology Consumer Acceptance of Online Banking : an Extension of the Technology Acceptance Model. Internet Research, 14(3). https://doi.org/10.1108/10662240410542652

Racherla, P., \& Friske, W. (2012). Electronic Commerce Research and Applications Perceived ' Usefulness ' of Online Consumer Reviews: An Exploratory Investigation across Three Services Categories. Electronic Commerce Research and Applications, 11(6), 548-559. https://doi.org/10.1016/j.elerap.2012.06.003

Ramayah, T., Jantan, M., Nasser, M., Noor, M., Ling, K. P., \& Razak, R. C. (2003). Receptiveness of Internet Banking by Malaysian Consumers: the Case of Penang. Asian Academy of Management Journal, 8(2), 1-29.

Sadeq, A. M. (2002). Waqf, perpetual charity and poverty alleviation. 29(1), 135-151. https://doi.org/10.1108/03068290210413038

Safiek Mokhlis. (2009). Relevancy and Measurement of Religiosity in Consumer Behavior Research. International Business Research, 2(3), 75-84.

Sekaran, U. (2003). Research Methods For Business (4th ed.). John Wiley \& Sons, Inc. Suhud, U., Wibowo, S. F., Khairi, A., \& Willson, G. (2019). Applying the Theory of Acceptance Model to Consumer Acceptance of Taxi-Hailing Mobile App. Journal of Internet and E-Business Studies, 2019, 1-10. https://doi. org/10.5171/2019.382593

Tang, J. E., \& Chiang, C. (2009). Towards an Understanding of the Behavioral Intention to Use Mobile Knowledge Management. Information Science and Application, 6(9), 1601-1613.

Wan Ahmad, W.M., Ab Rahman, A., Ali, N.A., \& Seman, A. C. (2008). Religiosity and Banking Selection among Malays in Lembah Klang. Shariah Journal, 16(2), 279-304.

Wulandari, D., \& Subagio, A. (2015). Consumer Decision Making in Conventional Banks and Islamic Bank based on Quality of Service Perception. Procedia Social and Behavioral Sciences. https://doi.org/10.1016/j.sbspro.2015.11.062

Waluyo, M. (2016), in Basuki, I. (Eds), Mudah Cepat Tepat Penggunaan Tools AMOS dalam Aplikasi SEM, Jawa Timur:UPN “Veteran” Jawa Timur 
This page is intentionally left blank 